\title{
THE POWER OF AMIRI BARAKA'S POLITICAL THOUGHTS TO THE AFRICAN-AMERICAN MOVEMENT IN AMERICA
}

\author{
Irma Febriyanti \\ Irma.febriayanti86@yahoo.com
}

\begin{abstract}
Imamu Amiri Baraka is an artist, activist, and also an African-American leader who was born in Newark, New Jersey. Throughout his prolific career in American literature, he was able to generate some important political issues in defending the Black Power which was a perpetuating challenge for African-American intellectuals in the 1960s-1970s.

This research is written under American Studies discipline, which takes politics to gain an African-American politics' point of view, sociology to explore the theory of race and social conflict in the United States, and cultural studies to understand the struggle of AfricanAmericans towards white Americans.

The findings of this research show Baraka's adeptness in his dual role as artist and politician through his political thoughts which has a never-ending development of his political consciousness. Baraka's intellectual and political thought formation has moved through very distinct stages and they are: Black Cultural Nationalism, Black Solidarity and Black Marxism. His final political stage has a broader consciousness that reveals capitalism in the Western world and this revelation of capitalism declared its theme of death and despair, moral and social corruption with its concomitant decrying Western values and ethics, the struggle against selfhatred, and a growing ethnic awareness.
\end{abstract}

Keywords: Amiri Baraka, black power, political thought, African-American politics, and conflict

\section{Introduction}

Over the course of political history in the United States, African-Americans have appeared in a long and rich spectrum. AfricanAmericans started their journey in the New World with a struggle for a long time to survive and thrive in a democracy originally conceived by and for Americans from Europe (Scott \& Shade, 2005). Ever since their ancestors were forced to be enslaved to the New World for nearly 400 years ago, they have persistently striven to overcome racial adversity. Even the significance and reach of the Civil Rights Act of 1964 signed by Lyndon Johnson 50 years ago live to inspire the nation up to this moment in 2015 and the striving events of African-Americans in gaining their equality are easily can be seen in many aspects of American life (Roy, 2014). Therefore, victories over slavery and the persistence of discrimination and repression towards them are still an important issue.

After the horrible and perpetuating life of slavery in America, African-Americans had to experience Jim Crow Law in the United States of America. This law is a term used to refer to the widespread practice of racial segregation instituted in the Southern states after the end of reconstruction. Robert C. Smith defined segregation as the practice of the enforced separation of the members of a subordinate group, ethnic group, or minority group from the superordinate group. In the United States this practice mainly involved the separation of whites from blacks. It was seen virtually in all aspects of life, while in the Northern states it was enforced mainly in housing, schools, and employment. Segregation was also enforced by the federal government in the bureaucracy, the military, and in various aspects of public 
policy. This segregation forced plenty of African-American leaders to stand up and precipitate the Civil Rights movement where political thought was needed in order to change African-Americans' positions in the society (Smith, 2003).

The politics of Black radicals which Amiri Baraka took part in contributing his political thoughts in the local black freedom movement in America which can be called as Black Marxism (Theoharis \& Woodard, 2005) was a result of Black Power Movement promoted by Malcolm $\mathrm{X}$ on the local, national, and international levels (Joseph, 2000). From the previous statements can be said that Malcom X's racial capitalism ideas after the Civil Rights movement, developed to be Baraka's political behavior: black radical. Hence, it was clear that Baraka was famous of his radical political behaviors and thoughts.

Amiri Baraka was chosen here for his abundant contributions on black intellectual activism. Baraka's experiences and involvements in intellectual activism reflected an African-American cultural tradition. This tradition was viewed as their way to survive as a family, or in this case: a community. A community of African-Americans takes part as the keeper of African-American legacy (McCoy, 2011). The community that he built and provided for the black youth and blacks in general could not be counted as a few. His contributions also rested in his spontaneous involvement in local black power politics, making of Newark a model of Black Nationalist influence within AfricanAmerican political culture in the $20^{\text {th }}$ century up to now. Through the Modern Black Convention Movement, Baraka established Newark's Black Power experiment to be not only as a black political convention, but also as a national prototype for the black liberation movement. This convention created black leadership which later formed the politics of cultural nationalism (Woodard, 1999). Baraka was a prominent political leader who made literature and his music as an agent of political socialization.

Amiri Baraka was the leading figure in the movement, articulating and advocating a variant of cultural nationalism in his poetry, criticism, and commentary. Baraka was well known for his strident social criticism, often writing in an incendiary style that made it difficult for some audiences and critics to respond with objectivity to his works. Most of his career and method in poetry, drama, fiction, and essays was confrontational, calculated to shock and awaken audiences to the political concerns of black Americans. For decades, Baraka was one of the most prominent voices in the world of American literature (Baraka, 2014).

\section{Methodology}

Dealing with a library research in this research, the researcher uses will use a qualitative research methodologically with a social constructivism as its perspective. As the title of this study is about the power of Amiri Baraka's political thoughts, the issue of politics will provide evidence to validate a particular view of the world, which is clearly vital to the discipline of political science. The methods, after all, are intrinsically linked to research findings. With the analysis of documents and archives, I will connect the chain of events in Amiri Baraka's life. As Creswell (2009) mentioned the definition of qualitative research is as:

a form of interpretive inquiry in which researchers make an interpretation of what they see, hear, and understand. Their interpretations cannot be separated from their own backgrounds, history, contexts, and prior understandings. After a research 
report is issued, the readers make an interpretation as well as the participants, offering yet other interpretations of the study. With the readers, the participants, and the researchers all making interpretations, it is apparent how multiple views of the problem can emerge. (p. 236)

With interpretative character, the case study begins with a detailed description of the incident such as the Black Power Movement, a chronology of the first two decades of events following the incident, and details about Baraka's political thoughts in dealing with the black struggle, the organizations he had made, and the conventions he had built for his community/society. Then, finally, the researcher uses will make an interpretation of those incidents and Baraka's efforts in merging elements of the Black Arts Movement and sections of Black Power Movement to fashion of politics of black cultural nationalism in the Modern Black Convention Center (Woodard, 1999).

This research consists of several materials which are a collection of original primary data and secondary data collected by the researcher. The primary data is undertaken after the researcher has gained some insight into the issue by reviewing secondary research or by analyzing previously collected primary data. The primary data covers Amiri Baraka's autobiography, books, and some theses related to Black Art Movement/Black Power Movement/Black Power Politics or Amiri Baraka's issues. The secondary data concerns on articles, website articles, journals, Amir Baraka's poetry collections and electronic books downloaded from the internet and also some theses' citations taken from graduate students of Universitas Gadjah Mada.

\section{Findings}

Amiri Baraka political stance was built and created through many events and conflicts, each of them contributed and influenced African-American community in American history. Baraka's political thoughts which had encouraged him to stand up for AfricanAmericans rights was influenced by certain social, cultural, and political background.

A social background examines and elaborates the position of Amiri Baraka as an individual who took place as an issue where he reflected his place and thoughts in the society. It was the unjust inequality that developed the most common type of internal conflicts in the making of Baraka's political thoughts. The domination of economic, cultural, or racial group was often manifested and authorized by white Americans and this produced the potential for conflict of such magnitude that it literary tears a society apart (Bartos \& Wehr, 2002).

The result of economic domination by white Americans forced black Americans without many choices to live equally in America. As an African-American, Baraka could not avoid his situation of economic domination; being a black middle class but described by American society as 'underdeveloped middle class'. It has practically no economic power, and in any case it is in no way commensurate with the bourgeoisie of the mother country which it hopes to replace their condition and situation with bare hands.

The neglect of African-American history brought its society into the United States of America without its own consciousness and this became a social background for this research. The social background that is related to Baraka's consciousness can also be seen through W.E. B. Du Bois' Souls of Black Folk which represent the voices of AfricanAmerican thinkers about how they were excluded from philosophical discourse for 
several reasons. Du Bois raised a powerful consciousness which the wider white community had ignored.

Without a powerful consciousness, the American history occasionally overlooks the experiences of powerless minorities and later reinterprets their contributions to American society (Harrison, 2011). Therefore, Du Bois tried to figure this out through his work which is marked with the ascendancy of analytic philosophy, logical positivism, language philosophy, and the view that philosophy's proper role is servant of science. This movement of shifting paradigm left the social and political activism behind in the new focus on scientific investigations.

The investigation gave an insight that "black folk" have a fundamentally different experience of the world in every wayemotionally, socially, politically, etc.-in virtue of being black. In a 1960s San Francisco Chronicle interview, Baraka explained about his experience in studying in Howard University majoring in English with a minor in philosophy, The Howard thing let me understand the Negro sickness... They teach you how to pretend to be white. This experience began a long-running condemnation of and disassociation from the black middle class or, as Baraka termed them in his interview with Henry C. Lacey' as "false Negroes" (Lacey, 1981).

Using a conflict theory, the term "false negroes" was caused by Baraka's consciousness contributed to understanding social conflict (its sources, the causes of escalation and de-escalation of violence, the negotiations process). The actual case of social conflict can be eliminate by having a political revolution because according to Karl Marx, political revolution has an ability to restrict the economic and social relations within the class struggle. One of African-
American class struggles in America can be seen through Baraka's refusal towards blacks' mainstream identity. This refusal was supported by his middle class community, which started to create their own society, which Baraka considered was detrimental to overall black culture.

For Baraka, the middle class later came to symbolize the failure of black arts, since, with more resources, middle-class blacks were in the best position within the community to explore literature, drama, and art beyond the mainstream concepts of white America. He tried to start and promote Blacks' identity without white interference to tell and define the definition of popular art should be. The black artists were expected to lift up black's dignity in the class struggle, from being underdeveloped middle class to be real American citizens.

As Franz Fanon described black middle class in America as "underdeveloped middle class," Baraka developed his consciousness by using art as a tool to change false identity given by white Americans. He said in 1962, "In most cases the Negroes who found themselves in a position to pursue some art [...] have been members of the Negro middle class, a group that has always gone out of its way to cultivate any mediocrity, as long as that mediocrity was guaranteed to prove to America [...] that they were not really who they were, i.e., Negroes" (as cited in Martin, 1995). Therefore, artistically he claimed that as long as the black middle class's aim was to be viewed by white America as not black, they would never be able to fully explore or cultivate a unique art form.

According to Bartos \& Wehr (2002) in Using Conflict Theory, a deepening sense of injustice as it was experienced by Baraka, was shaping a monumental grievance among blacks and sympathetic whites, a grievance 
soon to be transformed into overt conflict action in what is commonly known as the civil rights movement.

The Civil Rights Movement had a great value to black cultural nationalism for this movement had done many continuing efforts to renounce and claim their own culture to be a valuable part of American society. Without the fully admittance of black culture in American society, African-Americans were unable to have the same rights as white American citizens. Therefore, to see Baraka's cultural background, the researcher uses his point of view as a black man in the Civil Rights Movement to be related later on to his political thoughts. For a black man like Amiri Baraka, the Civil Rights Movement was a struggle against structural racism and for democracy for all, the African-American people continue to play a strategic role in the fight for progress. This culture of struggle is indelibly etched on the basic progressive and democratic political consciousness and basic character of the African-Americans (Tyner, 2014).

Similarly, many other black revolutionaries of that era, Baraka attempted to follow the path outlined by Malcolm X. Malcolm X's black ethos and his emphasis on the revolutionary black consciousness rouse the new nationalism in several of the most challenging lessons of Malcolm X: the modernization of black nationalism, the priority of black cultural revolution, the centrality of the African Revolution, and the necessity of developing a black ideology of selfdetermination, one reflecting the African American ethos (Woodard, 1999).

The popular themes such as selfdetermination, self-respect, and self-defense articulated by Malcolm X was an assertion of black pride and a reaction against the entire system of racism; blacks denounced white culture, institutions, behavior, and liberal racists (Woodard, 1999). A reaction against racism reveals how blacks' goal of equality has been incompatible with the goal of continued dominance by whites. AfricanAmericans were challenging this racism with law as well as word by the first decade of the twentieth century. The 'word' was formed into black writing where Baraka mentioned in his journal entitled Afro-American Literature and Class Struggle; it (the writing) was actually accompanied, reflected and exhorted rebellion.

The definition of cultural nationalism is a movement of moral regeneration which seeks to re-unite the different aspects of the nationtraditional and modern, agriculture and industry, science and religion-by returning to the creative life-principle of the nation. Furthermore, Hutchinson defines cultural nationalist as one who sees the essence of a nation as its distinct civilization, generated by its unique history and culture (Hutchinson, 1994).

This black cultural nationalism examined how Baraka's cultural politics contributed to the Black Power experiments in the 1960s and influenced the course of black nationality formation in the 1970s. Before Baraka's political thought emerged on this cultural nationalism, the politics of cultural nationalism was confined to a small circle of students, artists, and intellectuals. In terms of black nationality formation, it remained a head full of radical ideas but separated from the body of the black community (Baraka, 1976).

The new generation of militant Black Power was the first phase of Amiri Baraka's political development where it was a formative period during which he emerged as a revolutionary artist and a radical intellectual and in Newark, Baraka rose as the head of the Modern Black 
Convention Movement. Baraka's ability to translate his radical belief into sustain mass political action had shown America how his power of political thoughts was different from the previous black nationalist intellectuals who experienced important personal transformations, but they had extreme difficulties translating their radical beliefs into sustained mass political action (Hudson, 1973).

Even so, those personal transformations of writers were significant in Baraka's political thought because they had set the stage for the larger battles to come in the next black nationality formation. Baraka's moving narratives of individual transformation in Home along with Malcolm $\mathrm{X}$ in The Autobiography of Malcolm $X$ and Eldridge Cleaver in Soul in Ice constructed a radical black identity, purpose, and direction for many black activists. Those narrative, poetic, and dramatic accounts of self-transformation inspired millions in the black national community to imagine black nationhood in White America (Anderson, 1983). This was where Baraka had a role both as an artist and a cultural theorist, in association with Askia Muhammad Toure and Larry Neal, sparked the explosive Black Arts Movement, which galvanized thousands of African American artists and writers; this upsurge prepared the path for the politics of the Modern Black Convention Movement.

The ability to have a free communication was gained through black political convention which created a common culture by "averaging" the beliefs, values, and expectations that the individual members bring into the group (Bartos and Wehr, 2002). It is showed how free communication as a tool which produces so called communal values and in this case is; black culture. Moreover, free communication can also promote conflict solidarity and this solidarity was poured into
Baraka's political Thought in the Modern Black Convention Movement.

Between 1967 and 1972 the politics of black cultural nationalism crystallized in the Modern Black Convention Movement, and Imamu Amiri Baraka sought to establish Newark's Black Power experiment and its black political conventions as a national prototype for the black liberation movement. As a cultural nationalist, Baraka used the black conventions to represent the core of the nation becoming to the "liberation" or freedom of African-Americans.

Those conventions/assemblies were the gathering at which the nation took definitive shape. Thus, the black political assemblies were the centerpiece of Baraka's politics of cultural nationalism, that is, the heart of the strategy of nationality formation. Under Baraka's leadership, elements of the Black Arts Movement and sections of the Black Power Movement merged to fashion the politics of black cultural nationalism in the Modern Black Convention Movement. Baraka's black political convention signaled a new stage in black nationality formation, and that new identity and consciousness developed in the context of group conflict: black against white.

Conflict group between white and black Americans led Baraka to increase group solidarity. By forming a group solidarity to deal with the perpetuating conflict, Baraka interacted with his community fairly and regularly and using a conflict theory, this interaction is seen as a crucial ingredient of "groupness," not only because it establishes relationships between individuals but also because it tends to create features that are essential for a group's existence, such as group solidarity, identity, and culture (Homans, 1950). 
The formative political influences of Amiri Baraka was not only came from Malcolm X who had started a black national consciousness and contributed to the early development of the black freedom movement, but also from various revolutionary leaders from many other countries such as Fidel Castro (Cuba) and Mao Zedong (China) to Julius Nyerere (Tanzania) and Sekou Toure (Guinea). Different from Malcolm X, Amiri Baraka's path to black consciousness represents the other important route to Black Nationalism, the road traveled by students and revolutionary intellectuals who had been inspired him through all his youth from various countries.

Baraka was intensely affected by the political success of the Cuban revolution. In celebration of the revolution's victory over the Batista forces, Jones edited Fidel Castro, January 1, 1959, a small pamphlet of collected poetry by Kerouac, Ron Loewinsohn, Joel Oppenheimer, Gilbert Sorrentino, and Jones, among others. Less political than it might seem, the origins of the pamphlet lay in the Errol Flynn-like images through which Jones imagined Castro: "The Cuban thing seemed a case of classic Hollywood proportions" (Watts, 2001). In addition, Baraka's visit to Cuba and his encounters with some revolutionary leaders, such as Fidel Castro in Cuba, Mohammed Babu in Tanzania, Robert F. Williams and Malcolm X in Black Revolt took shape in the early 1960s and challenged his identity both as a writer and as a man (Woodard, 1999).

The emergence of black politics in Newark, New Jersey, was accompanied by "group trauma," the kind of "collective suffering" that stimulated the development of a collective nationality consciousness (Bayor, 1978). On issues ranging from public education to welfare, Baraka's intellectual role was to remake black political landscape. Different from the previous cultural nationalists before him who were the top-down middle class leadership of traditional black intellectual groups, Baraka fundamentally altered the composition of black leadership in his community to include a new cohort of neighborhood-based working class and female black community activists.

This strategy was a new and distinctive style of expressive politics crystallized in Newark, New Jersey; it was a dynamic movement combining the politics of black nationality formation with the modernization of cultural nationalism (Woodard, 1999). Placing the foundation for a black and Puerto Rican alliance was essential for the rise of the Black Power experiment in Newark; together African Americans and Puerto Ricans constituted some 65 percent of the city's population. Galvanized by an alliance of people of color against white racism, the campaign pulled various oppressed cultures of black, Latino, and progressive white voters under the banner of the Black and Puerto Rican Political Convention's "Community Choice" slate (Young, 2006).

This political thought of Baraka about modern black cultural nationalism drew a parallel between struggles against racial and class oppression in the US and movements abroad against colonialism and imperialism (Geary, 2008). The politics of cultural nationalism proposed a strategy of black liberation involving struggles for regional autonomy in urban centers and in this case, according to Baraka, they were the oppressed people of color in the United States: Puerto Ricans and Mexican Americans. The development of racial politics took place in formation with the rise of a second type of black ghetto in the United States (Woodard, 1999).

The most remarkable of Baraka's commitment to black cultural nationalism was that creative 
experimentation with organizations, agendas, and institutions was a way forward. $\mathrm{He}$ believed that African-American had a great storehouse of creative energy that urban youth had tremendous untapped potential that was essential to the regeneration of black America. It was the legacy of Malcolm X's black selfdetermination that Baraka used to intervene or mediate college students, artists, and intellectuals on the side of the grassroots, a great deal was possible (Allen, 1970).

Baraka's political thought on cultural nationalism was related to Black Art and black activism which played a vivid complexity in the concrete activism he was involved in. Being held from 1960s to 1970s, black cultural nationalism was a long struggle which characterized its long dynamics. He was conscious of the hardships that AfricanAmericans encountered during their search for identity, purpose and direction that shaped cultural nationalism. Black arts was one of the most important political experiments of Baraka which started from small circles of students and artists. However, the great lesson of struggle that Baraka had been done to his community was that he was committed to black cultural nationalism through creative and artistic experiments with organizations, agendas and institutions. It was the Modern Black Convention Movement that gave such a great storehouse of creative energy and that urban youth had tremendous untapped potential that was essential to the regeneration of black America.

From the earlier discussion the researcher has mentioned about how free interaction or free communication among blacks in the Modern Black Convention Movement (MBCM) promotes the creation of any culture (Homans, 1950) and promotes acceptance of common goals: so-called communal values (Bartos \& Wehr, 2002). However, seeing this through a conflict theory, free communication can also promote conflict solidarity. Some features that are essentials for a group's existence such as a group solidarity, identity, and culture, an interaction among the group of members are seen as a crucial ingredient. Not only it tends to create such features, but it also establishes relationships between individuals.

The struggle to achieve a black nationality formation developed a conflict culture within Baraka's community in Newark as the local political arena to the national political stage which marks the most important phase of the politics of cultural nationalism as well as the birth of a national political community (Woodard, 1999). MBCM was the genesis of that political community which supported four national organizations: the Congress of African People (CAP), the African Liberation Support Committee (ALSC), the Black Women's United Front (BWUF), and the National Black Assembly (NBA).

By bringing up the issue of black solidarity, Baraka blew up his own pride as an AfricanAmerican. His black pride tells us everything we need to know about his political thought. Just like Juliet Hooker in her Race and the Politics of Solidarity, Baraka viewed black solidarity not only as a political tactic, but also as the way his race works through the body, in a visual register, thus has the effect of spatially determining the boundaries of those whom he saw as his political and intellectual equals and those whose unmerited pain and suffering need not concern him,

Thus, in this case, racial seeing in black solidarity has tremendous consequences for gaining his political solidarity, as solidarity is crucially dependent on vision and imagination. Baraka's ability to create many creative and important black conventions together along with his arts has made him to be a great 
political leader and established a political transformation for AfricanAmericans in the United States. It is not accidental that solidarity is routinely described in terms of the capacity to envision a shared collective identity, which Baraka described it later as a collective suffering or collective injustice. (Hooker, 2009)

As the aesthetic and spiritual sister of the Black Power concept, the Black Arts Movement led by Baraka envisioned an arts that spoke directly to the needs and aspirations of Black America. The Black Arts Movement had given a belief where there would be an imminent demise of West and the simultaneous rise of the black world, which might have generated a vicarious sense of empowerment for they invoked a teleology of black emancipation (Watts, 2001). However Watts explained that kind of doctrine was a confusing analysis because it was an unlikely historical change that would ultimately bring the west to its knees and the African diaspora to ascendance. This was where Baraka entered his new consciousness towards some new groups who adopted a Marxism-Leninism.

Being committed to the improvement of his nation, as an artist, Baraka viewed that the values of Western capitalism did not fit the people of America. Instead, he believed that by approaching the ills of the nation through a Marxist worldview, individuals could come to a deeper resolution. His poetry during this period marked a seemingly never-ending development of consciousness, whereby Baraka did not operate as an individual but as a voice for the masses (Al-Otaibi, 2010). This was where Baraka's consciousness went wider into the Western world's history of imperialism which recited the long and perpetuable history of enslaved blacks in America.
Thus, Baraka's consciousness grew up wider from an ideology of race superiority and its inequality to a world of capitalism in a form of America, as Taylor Patrick elaborated race as an ideology in his examination of Fanon's theories, "race is emphasized over class, with the result that capitalist relations of production and the related social inequities remain untouched in the neocolonial regime", leading Nationalism to play into the hands of the oppressor rather than causing any real freedom of consciousness.

\section{Conclusion}

In the United States of America, AfricanAmericans have been living a perpetuating journey to gain an identity as a legal citizen. It took more than a hundred year to be treated equally, especially in American Politics. This research analyzes one of the black leaders in the United States named Imamu Amiri Baraka. Baraka was a prolific artist as he published many literature works with many political themes. He was well-known as a race leader for defending the AfricanAmerican race in the United States, but the way he used his political thoughts and ideas were quite different from the previous black leaders before him.

Choosing politics as his main weapon in facing the reality around him was brilliant since politics gave African-Americans more power in the American society to survive in the middle of race-conflict and class struggle in the United States. To analyze Baraka's political thoughts, this research is started with the theory of power which leads the readers to the central challenges facing American society: ideological conflict, crime and violence, racism and sexism, community problems, poverty and powerlessness, globalization, and international relations. 
The changing political thoughts of Baraka from time to time was reflected and represented through his changed name from Leroi Jones to Imamu Amiri Baraka. As an activist and artist at the same time, Baraka's quest to recover his consciousness motivated him to attempt and define black politics and black aesthetic. He accomplished this lifechanging identity by embracing pseudoAfrican traditions, an immersion in black community and culture, and a violent denial of the white and middle-class black bourgeoisie. When he changed his name from LeRoi Jones to Imamu Amiri Baraka, he assumed his role as a spiritual leader of a community, which was signified by the title "Imamu", and embraced a new identity. These alterations of his public self-signified his deep desire for change and the creation of a new conscious self and nation.

Baraka's ever-changing political thoughts which had encouraged him to stand up for African-Americans rights was influenced by certain social, cultural, and political background. The social background influencing Baraka's political thoughts were started from his own experience as a part of black middle-class. Being born as an AfricanAmerican in white dominations, Baraka grew up to be critical about his own society. There was a social conflict which led him to be conscious that without having a class struggle, African-American would remain an underdeveloped class. In other words, Baraka's social background could be traced back to the neglect of African-American history ever since it was started with a slavery bondage.

Not only social background which was important in the quest of Baraka's political thoughts, but also cultural and political background of Baraka as a race leader in the Black Power Movement. Baraka's cultural background in this research was begun with the Civil Rights Movement where the previous black leaders such as Malcolm X and Martin Luther King, Jr. articulated popular themes as self-determination, self-respect, and self-defense. It was a black pride's reaction against the entire system of racism; blacks denounced white culture or to put it differently it was a reaction against racism. While the social and cultural background related to the demand for Black Power to close a long chapter of legal segregation in American life, the political background of Amiri Baraka demanded a larger battle to come in the next black nationality formation. This black nationality formation was inspired and cause by racial oppression, nationality conflict, and ethnic competition in the United States, thus Baraka used politics in his own way as a tool to form his own aspirations as an artist and black intellectual.

The power of Baraka's political thoughts shows the functions of social conflict in the process of social change regarding and stressing on his ability of expressing and supporting African-American politics in his works as an ultimate tool. His political thoughts find the connection between power and social conflict in a society by providing a critical review of theorizing about the two domains, between white Americans and black Americans. Baraka's struggle for black liberation and equal opportunities in the U.S. after the Civil Rights movement in the 1960s showed his contributions in changing the social system. The researcher proposes some theories in studying this research with American Studies approach and those theories are Social-Conflict theory and AfricanAmerican Politics.

By revealing Amiri Baraka's attempt to redefine political and artistic expression to better reflect a black perspective, this research has explored the origins of Baraka's intellectual activism or in this term is named 
as Baraka's political thoughts. Baraka intellectual and political thought formation had moved through very distinct stages. As we could see from this research that throughout his prolific career, Baraka showed us the most important political experiments of political thoughts was the Modern Black Convention Movement where he planted a valid and new black culture to African-Americans, especially in Newark: the black nationality formation through Black Culturalism, the community control through Black Solidarity and a wider perspective of blacks in Black Marxism.

In Black Cultural Nationalism, the native intellectual remembered his authentic identity and kicks against attempts to assimilate him. He was able to recognize himself as part of the black community and a new black aesthetic tradition and, from this foundation, he moved to build a consciousness based on realism and action. This phase of political thought was his own cultural alienation, the native intellectual's attempts at cultural reaffirmation stop at romanticizations of bygone days corrected by philosophical traditions and aesthetic conventions borrowed from the world of the colonizer.

Black Cultural Nationalism did bring a huge impact for Black America, however, to prolong its value and existence in the United States, Baraka later promoted Black Solidarity to nurture a new generation of Black Power organizations under the Modern Black Convention Movement (MBCM) and led the convention to be a center for the development of national black leadership in a number of ways.

Finally, the last political thought of Baraka is: Black Marxism. As the third political thought, Black Marxism showed Baraka's expansive efforts of his shift to Marxism and the economics at the heart of the racial struggle. He believed that he was able to approach the ills of the nation through a Marxist worldview and inspired other minorities in America and around the world to come to a deeper resolution in dealing with capitalism.

Baraka has played an important role in the leadership of each of those three movements and their distinct ideologies, first as a cultural nationalist breaking conventions out of disillusioned rebellion, then as a black leader collecting and calling for black solidarity. $\mathrm{He}$ has worked tirelessly for the development of the world around him first on the basis of race and then on economics through his belief in Marxism.

The findings in this research show the twofold development of the poet and nation. This last chapter indicates that Baraka's ability to live up to the expected role of an artist using art and poetry as a weapon for social change is dependent upon and shaped by the ideological shifts and political fragmentation characterizing race in America.

Amiri Baraka had a broader consciousness that the reason behind this class oppression towards African-Americans were related to America being a huge part of capitalism in the Western world and it declared its theme of death and despair, moral and social corruption with its concomitant decrying of Western values and ethics, the struggle against selfhatred, and a growing ethnic awareness.

Having analyzed Baraka's political thoughts, this research is able to find that Baraka's political thought is a never-ending development of his political consciousness. This statement is taken from the study's major hypothesis that Baraka's different stances and poetic expressions attest to an everdeveloping, ever-changing consciousness centered on his identification as a black man in a Western world of capitalism.

\section{References}


Allen, R. L. (1970). Black Awakening in Capitalist AMerica. New York: Anchor.

Al-Otaibi, M. A. (2010). From LeRoi Jones to Amiri Baraka: The Development of a Black Poet's Consciousness. Riyadh: King Saud University.

Anderson, B. (1983). Imagined Communities. London: Verso.

Baraka, A. (1984). The Autobiography of Leroi Jones/Amiri Baraka. New York: Freundlich Books.

Bartos, O. J., \& Wehr, P. (2002). Using Conflict Theory. New York: Cambridge University Press.

Bayor, R. H. (1978). Neighbors in Conflict: The Irish, Germans, Jews, and Italians of New York City 1929-194. Baltimore: Johns Hopkins University Press.

Denzin, N. K. (2003). Reading and Writing Performance. Qualitative Research Vol. 3 (2), 243-268.

Geary, D. (2008). Soul Power: Culture, Radicalism, and the Making of a US. Third World Left. Journal of American Studies, Vol. 42, No. 2, 384385.

Harrison, B. C. (2011). Power and Society: An Introduction to the Social Sciences, Twelfth Edition. Boston: Wadsworth Cengage Learning.

Holliday, A. (2002). Doing and Writing Qualitative Research. Great Britain: The Cromwell Press Ltd.

Homans, G. C. (1950). The Human Group. New York: Harcourt, Brace and Company.
Hooker, J. (2009). Race and the Politics of Solidarity. New York: Oxford University Press, Inc.

Hudson, T. (1973). From LeRoi Jones to Amiri Baraka. Duke University Press.

Hutchinson, J. (1987). The Dynamics of Cultural Nationalism. London: Aleen and Urwin.

Joseph, P. E. (2000). Waiting Till the Midnight Hour: Reconceptualizing the Heroic Period of the Civil Rights Movement, 1954-1965. Souls , 6-17.

Jr., W. W. (1999). From Civil Rights to Black Liberation: Malcom $X$ and the Organization of Afro-America Unity. Boston: South End Press.

Martin, R. (1995, May 11). Historical Overviews of the Black Arts Movement. Retrieved from Modern American Poetry: http://www.english.illinois.edu/Maps/ blackarts/historical.htm

McCoy, R. (2011, 11 18). African-American Elders, Cultural Traditions, and the Family Reunion. Retrieved from American Society on Aging (ASA), Generations: http://www.asaging.org/blog/africanamerican-elders-cultural-traditionsand-family-reunion

Neal, L. (1968). The Black Art Movement. National Humanities Center Resource Toolbox: The Making of African American Identity Vol. III, 1917-1968, $1-2$.

Roy, A. (2014, July 31). 50 Years After The Civil Rights Act, Integration Remains Elusive. Retrieved from Forbes: http://www.forbes.com/sites/theapoth ecary/2014/07/31/50-years-laterintegration-remains-elusive/ 
Scott, W. R., \& Shade, W. G. (2005). Essays on African-American History, Culture and Society. Washington D.C.: U.S. Department of State.

Smith, R. C. (2003). Encyclopedia of AfricanAmerican Politics. New York: Facts on File, Inc.

Theoharis, J., \& Woodard, K. (2005). Groundwork: Local Black Freedom Movements in America. New York: New York University Press.

Tyner, J. (2014, February 19). AfricanAmerican struggles are key in the fight for progress. Retrieved from People Before Profit network: http://peoplesworld.org/african- american-struggles-are-key-in-thefight-for-progress/

Watts, J. G. (2001). Amiri Baraka, The Politics and Art of a Black Intellectual. New York: New York: University Press.

Woodard, K. (1999). A Nation within a Nation: Amiri Baraka (Leroi Jones) and Black Power Politics. North Carolina: The University of North Carolina Press.

Young, C. A. (2006). Soul Power: Culture, Radicalism, and the Making of a U.S. Third World Left. NC: Duke University Press. 
